\title{
Regional Government Policy in Preventing Illegal Drug Trade Case Study: North Sumatera
}

\section{Muhammad Novan Prasetya,}

Jurusan IImu Hubungan Internasional, Universitas Potensi Utama

Medan muhnovanprasetya@gmail.com

\section{Sahla Rizky Deovanka}

Jurusan IImu Hubungan Internasional, Universitas Potensi Utama Medan

\begin{abstract}
Indonesia with abundant natural resources and the location is in a strategic area in international trade is become an important factor to look at the increasing problem of drug trafficking. The important issue in Indonesia is the policy in the State of Indonesia is considered still lacking in terms of handling drugs. This research is a descriptive analytic research with qualitative methods. The author provides an overview and explain the efforts government in North Sumatra in tackling the trafficking and distribution of illegal narcotics are even already global.In ASEAN, Indonesia is the largest market for drug sales, while the country is the largest importer of China and Thailand. For Indonesia, geopolitics is the policy in order to achieve national goals by utilizing the advantages geographical position of the country is based on scientific knowledge about the geographical conditions. The network of drug syndicates from China who control distribution business in Indonesia.

In the area of North Sumatra, one of the sea track with high drug access is in Medan Belawan. BelawanPort, Medan is one of a number of ports that be the main concern of the apparatus because of prone to drug smuggling. In the region of North Sumaterawith the crusialstatus of acute drug, indicating that the handling of the border region of the ocean is still less to see the data obtained from the North Sumatra Police that the number of suspected cases of drug abuse in 2015 reached 6,267 people, and then increased in 2016 became 6,534 people. Belawan Pelawan Police Station itself occupies the second position with the number of 384 cases with 452 suspects. High incidence of drug abuse in North Sumatra is because North Sumatra region is the entrance and transit of drugs from outside to Indonesia.From the case study above, it
\end{abstract}


can be taken a center line of the vulnerability of the various policies related to drug abuse, then it is not possible the increase of drugs in the region of North Sumatra, Medan can be overcome.

Keywords: Regional Government Policy, Drug Trade, North Sumatera

\section{Introduction}

Narcotics is necessary for human treatment so that to meet the needs in the field of medicine and scientific studies required a continuous narcotics production for these patients. In Law Number 35 Year 2009 on Narcotics stated that narcotics on the one hand is a drug or a useful ingredient in the field of medicine or health services and the development of science and on the other hand can also also cause dependence when abused.

Indonesia with abundant natural resources and locations in strategic areas in international trade becomes important factors to see the increasing problem of drug trafficking. Indonesia is in the line of international trade. In addition to its archipelago territory, Indonesia is also a potential area for transit. Plus, with the existing natural and human resources in Indonesia. The important issue in Indonesia is the policy in the State of Indonesia which is considered still lacking in the handling of drugs.
Indonesia is a region with serious drug status. There are many found cases of narcotics abuse in Indonesia. In the era of globalization with the opening of all access to the world, drug abuse is increasingly widespread. Globalization relies on free access to various commodities, one of which is natcotics. In other words, in terms of distribution access, Indonesia has the potential to become one of the transit areas of narcotics trade. Indonesia strategic (cross position), has become a drug producing country. This can be seen by the disclosure of some drug laboratories (clandenstin lab) in Indonesia. Globalization is marked by the advancement of communication technology, trade liberalization and the rapid progress of the tourism industry has made Indonesia as a potential drug producer country which in the end may cause a disturbance of national security (Travel, 2016).

\section{Formulation of The Problem}

Based on the background of the problems described above, it can be 
formulated the following problems: How is the implementation of Indonesian government policies to deal with problems related to Narcotics abuse that is increasing?

\section{Objectives and Benefit}

Based on the problems that have been mentioned above, the objectives and benefits to be achieved in this study are:

1. To find out the extent of the development of illicit drug trafficking that has occurred in Indonesia, especially the area of North Sumatra?

2. To know how the role of Local Government of North Sumatra in handling phenomenon related illegal drug trade which is increasingly increasing?

\section{Research Method}

This research is a descriptive analytic research with qualitative method. According to Nazir (1988: 63) descriptive method is a method in examining the status of a group of people, an object, a set of conditions, a system of thought, or a class of events in the present. The purpose of this descriptive study is to create a description, systematic, factual and accurate description of the facts, traits and relationships among the phenomena under investigation. The authors provide an overview and explain the efforts of local governments in the region of North Sumatra in tackling the trade and circulation of illegal narcotics that even worldwide. The data presented is secondary data obtained through literature review, ie by collecting data relevant to the issues discussed from the literature such as books, newspapers, or magazines and websites from the internet. Data analysis technique used is qualitative data.

\section{Literature Revview The Definition of Narcotics}

Narcotics according to Article 1 number 1 Law Number 35 Year 2009 on Narcotics is a substance or drug derived from plants or non-plants, either synthetic or semisynthetic, which can cause a decrease or can change awareness, loss of taste, reduce to eliminate pain, and can cause dependence, which is divided into classes. The emergence of the hallucinatory effects of Narcotics use also causes the community groups, especially among teenagers to use Narcotics even though they do not suffer anything. This is what causes the abuse of Narcotics (drugs). The danger when using Narcotics when not in accordance with the rules is the existence of drug addiction (addiction). 
Detailed classification of narcotics is set forth in the provisions of Article 6 paragraph (1) of Law No. 35 of 2009 on Narcotics and the explanation that narcotics can be classified into three categories (batan, 2003):

1. Narcotics class I are narcotics that can only be used for scientific development purposes and not used in therapy, and have high potential to cause dependence. As for the type of narcotics class I mentioned there are 65 types of them: Cannabis, Plants Papaver Somniverum $\mathrm{L}$, raw or ripe Opium, Koka Plants, raw Cocaine, etc.

2. Narcotics Group II is a efficacious narcotic for treatment that is used as a last resort and can be used in therapy and has high potential to cause dependence. Type II narcotics are very numerous among others: Morphine, Alfasetilmetadol, Benzetidine, Dimenoksadol, Levorfanol, etc.

3. Narcotics Group III is a drug that is efficacious for treatment and widely used in therapy and has the potential to be lightly dependent. Type III narcotic drugs include: Ethylmorphine,
Nikokodina, Polkodina,

Buprenorfina.

\section{History of Narcotics}

Opium is known as one type of narcotics used by a small part of society, Candu allegedly comes from the Mediterranean Mountains east. Opium is a kind of wild bush that grows in mountainous areas. At first the seeds of the plant were taken to be used as a mixture of tea drinks(Travel, 2016). Opium addiction became a major problem in China after China became the main target of opium trade by British airlines, British East India Company

/ BEIC and the Netherlands. In 1970, BEIC sold opium to China. In 1983 there was an opium war I after the dark British opium was canceled by China. Britain and China fought back in 1856-1858 which made defeats on the Chinese side. As a result, China was forced to open the door and put opium through some at the port (Mardani, 2015).

In the United Nations report on the International Seminar on Prevention and Recovery of Addiction to Drugs in Bangkok in 1979, the Chinese migration story from the south to Southeast Asian countries at the end of the 18th century occurred due to the dry season and the threatening 
famine. With this migration then brings the habit of sucking opium into a new place. This again became an advantage for the colonists of Europe. As a result, until the late 19th century opium trade became a lucrative object in Southeast Asia. Because of this, then it is suspected that the country carrying opium is introduced by the Indians, Arabs, and Chinese themselves.

After becoming a VOC luggage, the import of opium in Java increased especially after the VOC held a monopoly of imports to the kingdom of Mataram then wilaya Sultanate of Banten. With technological advances, opium derived from Paaver Somniferum $\mathrm{L}$ fruit can be processed to producing morphine and heroine. While coca plants can be processed to produce cocaine. And there is also a marijuana that thrives in the country of Indonesia and includes one type of narcotics that banned the government. And now, opium, morphine, heroine, cocaine, and marijuana are known in terms of legislation as narcotics(Mardani, 2015).

\section{Concept of Narcotics Trade} (territorial focus)

\section{Indonesia-China}

According to Kastia (2001)
Indonesia-China

diplomatic relations began in 1950. This initial relationship has not provided a productive relationship, because the domestic situation of Indonesia and China is being preoccupied with the process of reconstruction in an atmosphere of revolution. IndonesiaChina diplomatic relations were frozen in October 1967 after the screening of G30S/ PKI, in addition to China's role in assisting PKI at that time. China's efforts to reopen diplomatic relations with Indonesia were visible in 1985-1988. Indonesia at that time did not provide any feedback, as the G30S / PKI event left political doubt for Indonesia to normalize the Indonesia-China

(Koesmawan, 2010).

The restoration of IndonesiaChina diplomatic relations marked the official visit of the Prime Minister of China to Indonesia in 1990 with the signing of the Momentum of Understanding on the restoration of diplomatic relations, as well as the signing of a cooperation agreement on economic and trade between the two countries.

\section{Indonesia-China}

bilateral relations in economic, trade and technical cooperation during the 1990/2000 period generally increased. In the field of tourism 
is expected to increase mainly from China to Indonesia. After simplifying the immigration procedure and after Indonesia by China is designated as an approved destination status. Minister of Tourism and Arts, said as many as 1.3 million Chinese tourists enter
Indonesia (Zulihar, 2012). In other words, the state of China as one of the foreign exchange suppliers for the state of Indonesia. However, on the other hand, China is also one of the main narcotics suppliers to Indonesia.

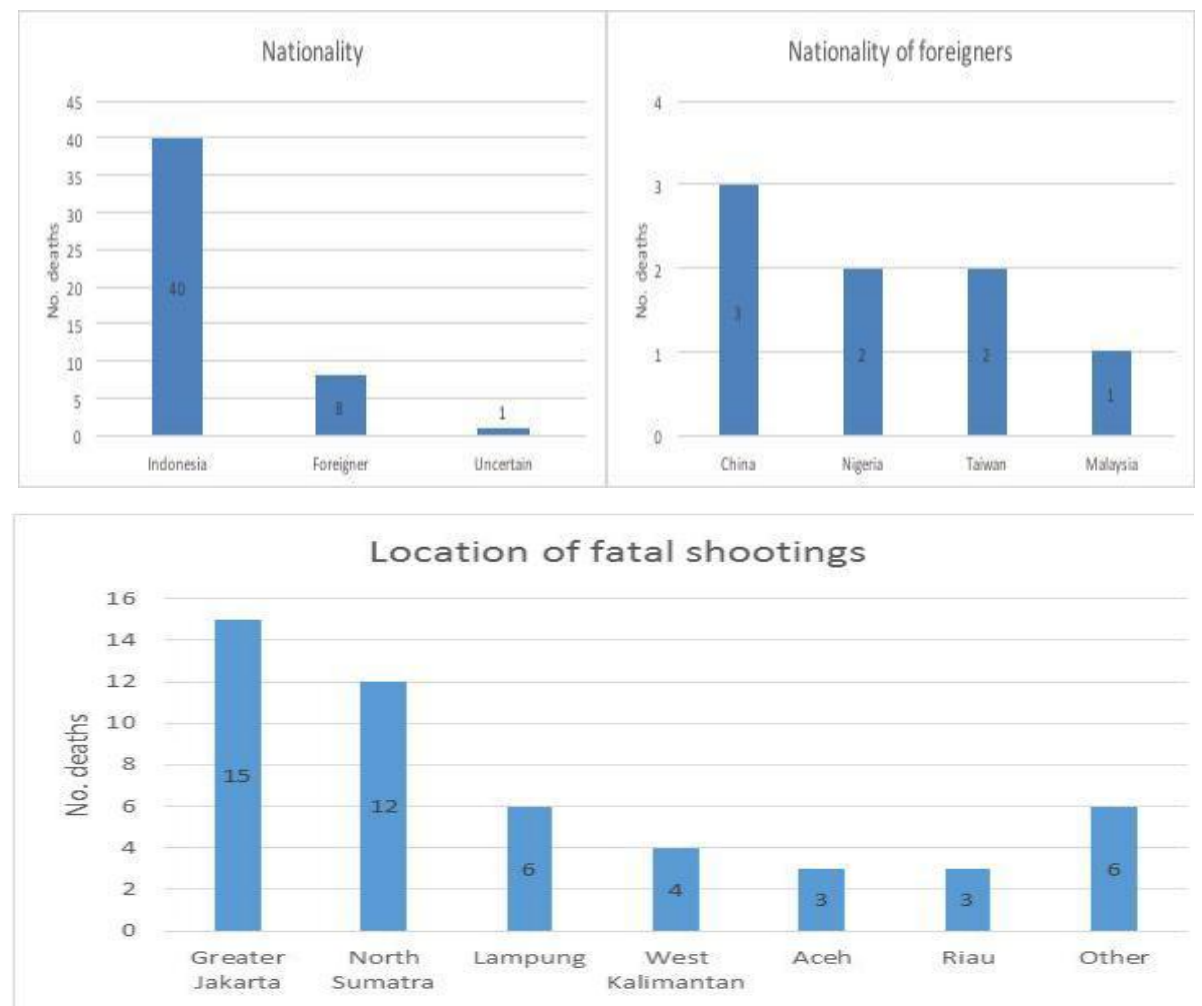

Source: various Indonesian media reports

This became a polemic in punishment is the death penalty. diplomatic relations between the However, this will turn out to be two countries. As is known, the case of abuse of narcotics, the toughest detrimental to diplomatic relations between the two countries. 


\section{Discussion}

Government of Indonesia's Policy on Arrangement of Narcotics Act.

At first, Ordinantie Regie(Regie, 2012), during this period of administration, each region has its own ordinant regie, such as: Bali Regie Ordonantie, Aceh Regie Ordonantie, and Borneo Regie Ordonantie. Next formation of rules Verdovende Midellen Ordonantie adjusted based on concordance, for the purpose of unification of law unifying all previous narcotics regulations. The third is Law No. 9 of 1976 on narcotics is a change that occurs in terms of setting a wider scope and more severe criminal threat. Next Law No. 22 of 1997 which underlies the enactment of this regulation is to increase supervision as an effort to prevent and combat the abuse and illicit trafficking of narcotics.

Finally, Law No. 35 of 2009 is that Narcotics crimes have been transnational in nature carried out using high modus operandi, advanced technology, supported by an extensive network of organizations. The new law aims to regulate eradication efforts against narcotics through the threat of criminal sanctions: imprisonment, life imprisonment and capital punishment(Ayat, 2009). Then in the framework of the prevention and eradication of illegal abuse and trafficking of Narcotics and Narcotics Precursor, with this Act was established National Narcotics Agency (BNN) duty and responsible directly to the Government in implementing eradication and abuse and illicit traffic Narcotics and Narcotics Precursor.

\section{Drug Status}

Presented by Komjen Pol Budi Waseso Head of The National AntiNarcotics Agency (BNN) that the number of drug users in Indonesia until November 2015 reached 5.9 million people. Indonesia has emergency dangers of drugs. Earlier in June 2015 recorded 4.2 million. Can be seen an increase in the number of Drug users even in a matter of months only. In ASEAN, Indonesia is the largest market share for drug sales, while the largest importing countries are China and Thailand(Sudarwan, 2017). 


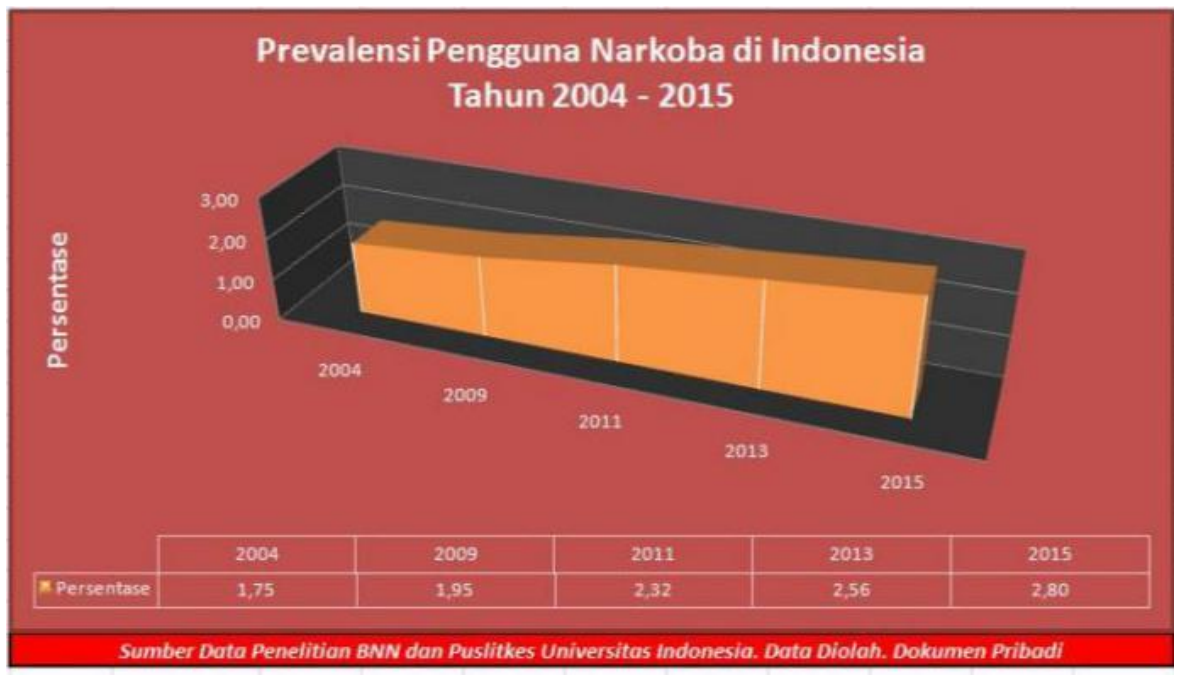

Geopolitics: Drugs in the Indo- location, the country's territorial

\section{China Area}

Geopolitics is interpreted as the science of state organizers whose policies are linked to the geographical problems of a region or place of residence of a nation. Geopolitics is the study of the relationship between geographic factors, strategy, and politics of a country, while for its implementation required a strategy that is national (Ermaya Suradinata, 2001). In particular, geopolitics is a method of foreign policy analysis, which seeks to understand, explain, and predict international political behavior especially in terms of geographic variables. This geographical variable refers to: the country's geographic climate, demographics, resources and technology development.

In other words, geopolitics is a political system in the form of national policies and policies that are driven by the national aspirations of state geography that if implemented and succeed will have a direct impact on the political system of a country. Conversely, the politics of the country will directly affect the geography of the country concerned. Geopolitics relies on social geography, about the geographical situation and everything that is considered relevant to the geographic characteristics of a country(Teori, 2015). For Indonesia, geopolitics is 
a policy in order to achieve national goals by utilizing the advantages of geographical location of the country based on scientific knowledge of the geographical conditions. The mode of illicit trafficking of international narcotics always involves foreign nationals and affects the territory of two or more countries and is always preceded by preparation or planning that is conducted outside the territorial boundaries of certain countries(Godson, 2002).

Head of Public Relations BNN Kombes Slamet Pribadi said China is the largest narcotics supplier to Indonesia and also controlling the drug business. Currently, the syndicate of narcotics network from China which is in control of business circulation in Indonesia(Tempo). It is proved by the case of the seizure of drugs from three different citizens involving Chinese citizens. With the shipping mode using the sea lane from China the 24 kilogram shabu it is placed into Chinese tea packaging and another 16 kilograms are stored in the machine tool loom that is shipped directly from China. According to the statement of the suspect, shabu was imported directly from China to Malaysia and smuggled in Aceh which then brought to Medan(Waluyo, 2017).

The territorial waters of Indonesia are required to receive serious attention and supervision from the Government. Drug syndicates began to choose the sea as a new route of drug distribution after the arrest of three Chinese nationals carrying $157 \mathrm{~kg}$ of shabu. The sea lane is chosen because of its vast territory and the supervision of the distribution of goods through the path is not as tight as the airport. Attributed to the BNN case that once arrested a drug syndicate using a ship as a means of distribution in North Sumatra. Mentioned that the shabu is shipped alone from China through the expedition services of marine vessels to be circulated in Indonesia (Raymandus).

\section{Illegal Drug Trafficking in North Sumatra}

In illicit drug trafficking, the authors will only focus on the many abused types of narcotics and then illegally trade in marijuana and ATS. BNN revealed drug users in Indonesia increased from 2015 to 2017 (Desideria, 2017). 


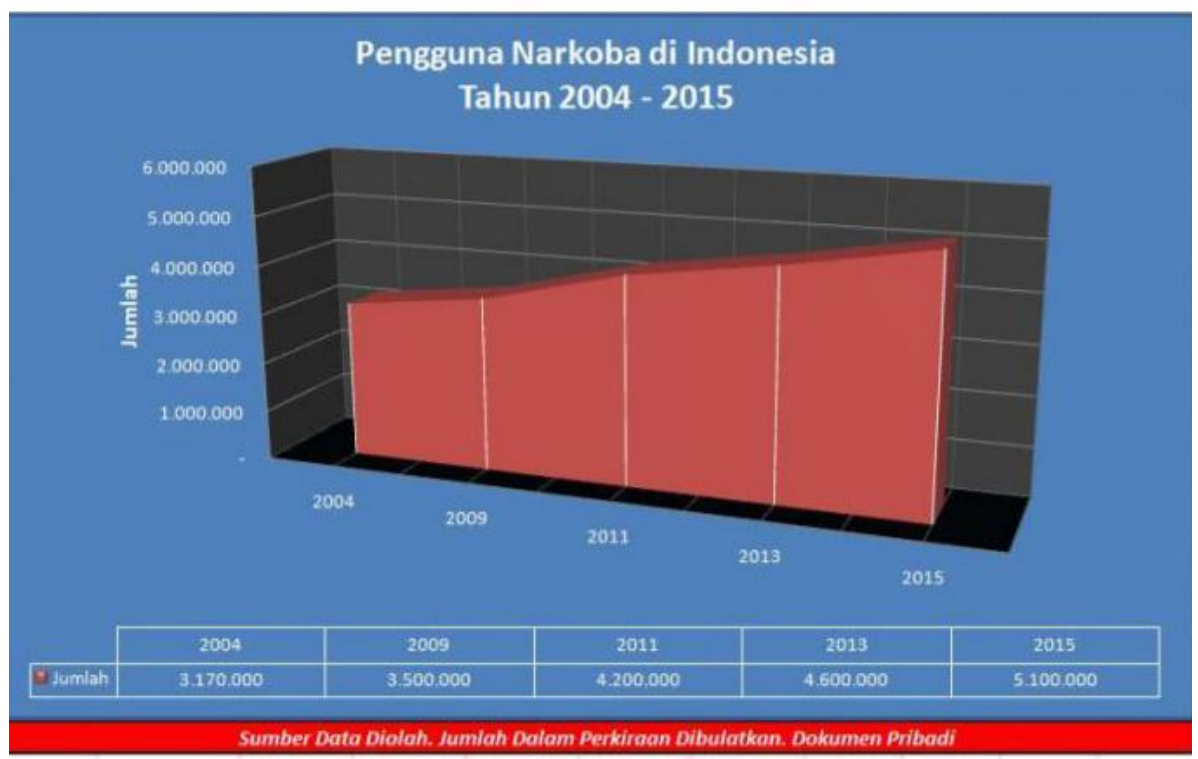

Then followed by ATS (Amphetamine Type Stimulant) or often known as meth and ecstasy. Disclosed by Head of National Narcotics Agency (BNN) Anang Iskandar that shabu is the most abused type of narcotics because it tends to be mild. Although the actual consumption of shabu make a bad impact in the long term that is $10-15$ years later. Then the second drug is marijuana. And the third is a pill-shaped ecstasy.

ATS is one of the illegally made drugs in the laboratory in tablet form. Ecstasy will encourage the body to perform activities that exceed the maximum limit of the body's own strength. Lack of body fluids can occur as a result of the high and long labor deployment, which often leads to death. Symptoms arising from the use of amphetamine include increased vigilance, arousal, and insomnia. Cannabis is known to trigger psychosis, especially for those who have genes. Cannabis can also trigger and confuse between anxiety and depression. Symptoms such as pleasure, depression and often drowsiness and self-control and lack of concentration (dedihumas, 2017).

The black market is a sector of economic activity involving illegal economic transactions, especially the illegal buying and selling of merchandise one of which is drugs here. The black market is said to be growing as the restrictions on places of the country get heavier, 
such as during bans or distributions. However, black markets are normally present in the economy of capitalism and socialism. The black market is very closely related to smuggling. Self-smuggling is any form of process of exporting goods that is prohibited or restricted by means of unlawful means.

Drug abuse is not just happening in urban areas, but has reached the countryside. Drug abuse shows symptoms that have reached a very alarming level both in terms of number of use, increasing drug variations, and how to use. Similarly, concerning illicit drug trafficking, it is known that trade is a form of cooperation between two or more parties that can bring benefits. Illicit trafficking in drugs can create an access or new path that regulates illegal drug trafficking.

The illicit drug trafficking that has taken place in Indonesia to date and has spread to all levels of society has made Indonesia feel the need to revise a written law that has been determined but it is increasingly adding to the cases of illicit trafficking (Erasmus, 2017). The nature of the crime systematized and supported by the mechanisms used so as to be able to compete with the fact that there are still many countries that are not sufficient legal provisions and the scope of the wider and the existing policy interventions of most countries, so often the handling of trade issues illicit drugs is not optimal.

Although in medicine most drugs are still useful for treatment, but if misused and even more if accompanied by circulation in the illegal path will result very harmful for individuals and the general public, especially the younger generation. Indonesia today is not only a transit of illicit trade and the purpose of drug trafficking, but has also become a manufacturer and exporter(Indonesia, 2008). Like the law of economics, as has been explained before that the more banykanya drug users in Indonesia this is clearly directly proportional to the number of requests. Large demand then results in a large supply as well. Not to mention the huge velocity of money that will make more and more people wanting to cultivate business with these lucrative profits.

It is known that the network that has been widespread related illicit drug trafficking case is even already organized. Illicit trafficking of drugs has become a crime that involves not only the lower classes, but also the upper classes that should be a good example for all Indonesian citizens. 
As a Trisakti University Money Laundering Money laundering Specialist (TPPU) expert Yenti Garnasih thinks that Indonesia is a haven for drug dealers. So the drug used as a very profitable trading business supported by the market price of drugs in Indonesia is higher than other countries in Asia(K.M, 2015) .

It is said that the price of drugs per package or per kilogram in Japan is only one fifth of the price in Indonesia. The selling price of goods coming from overseas to Indonesia increased many times over. This is what became one of the causes of drug crimes in Indonesia is higher. Despite having a clear narcotics law, but the fact is narcotics in Indonesia is getting higher and higher because of this narcotics trade has a very wide network. And globally, drugs ranks at the top in international illegal trade that amounts to 300 to 350 billion US dollars per year.

The phenomenon of illicit drug trafficking that occurred among Indonesian society has triggered the causes. Although it is clear that the impact of the losses and laws received in relation to illicit drug trafficking, it still can not be stopped. Illicit trafficking of drugs that have involved and impacted all levels of society is not considered to be detrimental to the parties concerned because it is balanced with the results obtained. How not, as happened in one of the provinces in Indonesia, the business of buying and selling drugs can produce a fantastic profit of 6 billion with only takes four months(Hukrim, 2015).

Actually, the business of buying and selling drugs that run this requires a very large capital to then earn a profit equal to even greater. Because to run this illicit drug trafficking is not only from the upper class who have enough capital, but the fact many people under the community who are involved with the reasons of difficulty finding employment(Siswanto, 2017). As stated earlier, that this illicit drug trafficking case is a crime that is not only in a closed but actually well structured and can be done anywhere.

The impact of drugs that can provide calm for the user then used as a drug that can relieve stress and create unconscious dependence. The number of cases of drug use among celebrities, state officials, even police officers make drugs more clearly felt necessary. Just imagine if the demand for the sale and purchase of drugs required by most of the upper class, who is not interested to sell with a big profit with security 
is guaranteed because the request came from one of the police.

The trafficking of drug trafficking that has been systematically organized and then glanced Indonesia as a potential market for international drug syndicates. This is because Indonesia has a large population, weak law enfor- cement and security, high drug user numbers, and unfavorable conditions(News, 2017).With the difficult economic situation, the number of unemployed, and the inadequate needs due to lack of income causes not a few people who decide to engage in illegal activities in order to get big profits, fast, and easy despite the risk. Drug trafficking can also be said to be one of the easiest businesses to enter Indonesia by requiring only resources and funds. Until now, it can be said that Indonesia has now become one of the main routes in the drug trade. Indonesia ogled because it is considered as a great market and good price (kompas, 2017).

1. Data states that the entrance of Narcotics to the Indonesian territory by sea is $80 \%$ while the remaining $20 \%$ by land and air. In the area of North Sumatra, one of the sea lane with high drug access in the area of Medan Belawan. Belawan Port,
Medan became one of a number of ports of particular concern to the authorities because of the prone smuggling of drugs. 88 percent of drug smuggling from the sea by utilizing cooperative services to enter drugs so the mode can run smoothly because it has proximity to the local authoritie(F, 2016). As ever, police arrested three cooperative managers by confiscating some evidence related to drug smuggling.

2. Uncontrolled supervision is also one of the causes of drug trafficking in Indonesia. In North Sumatra, with the increase of drug-bad status, it indicates that the handling of the maritime border areas is still less than the data obtained from the Police of North Sumatra that the number of suspected cases of drugs in 2015 reached 6,267 people, and then increased in 2016 to 6,534 people. Polres Pelawan Belawan itself occupies the second position with the number of 384 cases with the number of 452 suspects. The high number of drug abuse cases in North Sumatra due to the North Sumatra region is the entrance and transit of drugs from outside to Indonesia. 
3. Due to demand from consumers in need of imported drug supplies, increasing drug abuse can be seen from the many prisoners of drug cases in prisons

4. Strategic distribution is telling. Drug distribution strategies are conducted in stages-disconnected from supplier to user level. Similarly, the withdrawal of money from the sale of drugs, also done in stages-cut off to the collecting level. The modus operandi distributed by the drug syndicates is by using a variety of ways, including body packing, swallowed, hidden in certain items that are not thought in general. The modus operandi uses certain parties to open banking accounts and utilize money changer services either legal or illegal(Asril, 2016).

From the above case study, it can be drawn a midline about the weakness of various policies related to drug abuse, it is not impossible that the increase of drugs in North Sumatra, Medan can be overcome. Narcotics distrbusi access is one of the important points in the effort to handle narcotics abuse in Medan. This can be seen from the number of entry gaps for the distribution of narcotics. Of course this handling is not easy to be done by certain parties, but must be followed by cooperation from various parties such as customs, pelindo, BNN, and the police.

\section{Conclusion}

Indonesia is a region with serious drug status. There are many found cases of narcotics abuse in Indonesia. In the era of globalization with the opening of all access to the world, drug abuse is increasingly widespread.Globalization relies on free access to commodities, one of which is narcotics. In other words, in terms of distribution access, Indonesia has the potential to become one of the transit areas of narcotics trade. Indonesia strategic (cross position), has become a drug producing country. For Indonesia, geopolitics is a policy in order to achieve national goals by utilizing the advantage of geographical position of the country based on scientific knowledge about the geographical conditions. The mode of illicit trafficking of international narcotics always involves foreign nationals and affects the territory of two or more countries and is always preceded by preparation or planning that is conducted outside 
the territorial boundaries of certain countries.

China as one of foreign exchange supplier to Indonesia But on the other hand, China is also one of the major narcotics suppliers to Indonesia. became a polemic in diplomatic relations between the two countries. As is known, the case of abuse of narcotics, the toughest punishment is the death penalty. However, this will turn out to be detrimental to diplomatic relations between the two countries. In the area of North Sumatra, one of the sea lane with high drug access in the area of Medan Belawan. Belawan Port, Medan became one of a number of ports of special concern to the apparatus because of the prone smuggling of drugs.

\section{References:}

\section{Books}

Badan narkotika nasional, pedoman pencegahan penyalahgunaan narkoba bagi pemuda, BNN RI, Jakarta, 2004, hal 125

Hady, Hamdy, 2001, Ekonomi

Internasional: Teori dan Kebijakan Perdagangan Internasional (Buku I), Ghalia Indonesia, Jakarta
Nicholas Dorn, Drugs trafficking: Drug markets and law enforcement, London, 1992 hal 23

Subagyo Partodiharjo, Kenali narkoba dan musuhi penyalahgunanya, Jakarta,

Esensi, 2006. Hal 36

United Nations Ofice on Drugs and Crime. 2010. World Drug Reports. Vienna

Wang Mengkui, 2000. China's Economic Transformation Over 20 Years, Beijing

\section{Journals:}

Kiki Rizqi, Kerjasama United Nation Office On Drugs and Crime (UNODC) dengan Pemerintah Indonesia dalam Menangani Perdagangan Narkoba di Indonesia, eJournal Ilmu Hubungan Internasional, 2015, 3 (2): 233-244

eJournal Ilmu Hubungan Internasional, Volume 1, Nomor 3 , $2013: 857-866$

Koesmawan, Penentuan Jenis Komoditas Ekspor Indonesia ke China: Pemanfaatan Hubungan Perdagangan Indonesia China, Jurnal Ekonomi dan Bisnis No. Jilid 7, 2002, hlm 7 .

Nurul Huda \& Zulihar, Perdagangan Bilateral Indonesia-China 
Periode 2000-2009, Volume 6

Nomor 3, Desember 09

Phil Williams \& Roy Godson, Crime, Law \& Social ChangeAnticipating Organized and Transnational Crime, 2002. Hlm 322

\section{Websites:}

Anonim. Pengertian dan Jenis Metode Deskriptif , https:// idtesis.com/metode-deskriptif/

Anonim, Selama 2016, Kasus Narkoba di Sumut Meningkat, https://www.google.co.id/amp/ edisimedan.com/selama-2016kasus-narkoba-di-sumutmeningkat/amp/

Achmad Zulfikar F, 88 Persen Narkoba Masuk Melalui Pelabuhan Laut, https://m. metrotvnews.co/welcome-p a ge / n e w s / M k M Yv V k 88persen-narkoba-masukmelalui-pelabuhan-laut

Andylala Waluyo, Mabes Polri Ungkap Sindikat Perdagangan Narkoba dari China, https:// w w w. g o og le.com/a m p / w w w. vo aindonesi a . com/ amp/3379085.html

Erasmus , Peraturan Bersama Narkotika Diragukan, Lebih Baik Merivisi UU Narkotika Indra Akuntono, Presiden Jokowi: Indonesia Gawat
Darurat Narkoba, https:// w w w. g o o g l e . co.id / a mp / nasional.kompas.com/amp/ $\mathrm{read} / 2015 / 02 / 04 / 103311931 /$ P r e side n. J o k ow i . Indonesia. Gawat.Darurat. Narkoba?client $=$ ms-androidasus

King Travel. Pencegahan dan Penanggulangan Penyalahgunaan Narkoba, http:// i d . s hv o o ng. c o m / s o c i a 1 sciences/education/1900061pencegahan-dan-penanggulangan-penyalahgunaannarkoba/

Nasional.kompas, Indonesia Great Market dan Good Price Perdagangan Narkoba, https:// w w w. g o o g l e . c o $\mathrm{m}$ / a $\mathrm{m} \quad \mathrm{p}$ / $\mathrm{read} / 2012 / 06 / 07 / 15223854 /$ indonesia.Great.Market.dan. Good.Price.Perdagangan. Narkoba

Peter Reuter. 2009. Systemic Violence in Drug Markets. springerlink.com

Sabrina Asril, Enam "Money Changer" Jadi Perantara Bisnis Narkoba, https:// w w w. g o o g l e . c o m / a m p / nasional.kompas.com/amp/ $\operatorname{read2017/01/30/18493241/~}$ enam.money.changer.jadi. perantara.bisnis.narkoba 
